\title{
Supported self-care for children and adolescents with chronic disease and their families
}

\author{
Autocuidado apoiado a crianças e adolescentes com doenças crônicas e suas famílias \\ Auto cuidado apoyado a niños y adolescentes con enfermedades crónicas y sus familias
}

\section{Leiliane Teixeira Bento Fernandes', Vanessa Medeiros da Nóbrega', Maria Elizabete de Amorim Silva', Amanda Narciso Machado', Neusa Collet'}

' Universidade Federal da Paraíba, Postgraduate Program in Nursing. João Pessoa, Paraíba, Brazil.

How to cite this article:

Fernandes LTB, Nóbrega VM, Silva MEA, Machado AN, Collet N. Supported self-care for children and adolescents with chronic disease and their families. Rev Bras Enferm [Internet]. 2017;70(6):1318-29.

DOI: http://dx.doi.org/10.1590/0034-7167-2016-0553

Submission 08-18-2016 Approval: 02-10-2017

\begin{abstract}
Objective: analyze the scientific production between 2006 and 2015 on strategies for supported self-care by children and adolescents with chronic disease and their families. Method: integrative review of the literature conducted July and August 2016 in the databases: BDENF, LILACS, IBECS, ADOLEC, MEDLINE/PubMed and SCIELO. The 27 selected studies were analyzed and categorized into the five pillars of supported self-care: evaluation, counseling, agreement, care and accompaniment. Results: only two studies covered all five pillars, evaluation was considered most, but accompaniment was essential for adherence to the therapeutics of the goal plan. There was a prevalence of actions to evaluate the emotional state of the child/adolescent/family and technological interventions to empower the individual in self-care. Final considerations: these actions are concentrated in countries with health systems directed to the health needs of people with chronic disease. In Brazil, this is still incipient, since the actions are focused on exacerbation.

Descriptors: Child; Adolescent; Family; Chronic Disease; Self-Care.
\end{abstract}

\section{RESUMO}

Objetivo: analisar a produção científica entre 2006 e 2015 sobre estratégias para o autocuidado apoiado de crianças e adolescentes com doenças crônicas e suas famílias. Método: revisão integrativa da literatura realizada entre julho e agosto de 2016 nas bases de dados: BDENF, LILACS, IBECS, ADOLEC, MEDLINE/PubMed e SCIELO. Os 27 estudos selecionados foram analisados e categorizados nos cinco pilares do autocuidado apoiado: avaliação, aconselhamento, acordo, assistência e acompanhamento. Resultados: apenas dois estudos abarcaram os cinco pilares, sendo o mais evidenciado a avaliação, porém o acompanhamento se mostrou imprescindível para adesão às terapêuticas do plano de metas. Prevaleceram as ações, avaliação do estado emocional da criança/adolescente/família e intervenções tecnológicas para empoderar o indivíduo no autocuidado. Considerações finais: as referidas ações estão concentradas em países com sistemas de saúde direcionados às necessidades de saúde de pessoas com doenças crônicas. No Brasil, isso ainda é incipiente, pois as ações estão centradas em agudizações.

Descritores: Criança; Adolescente; Família; Doença Crônica; Autocuidado.

\section{RESUMEN}

Objetivo: analizar la producción científica entre 2006 y 2015 sobre estrategias para el auto cuidado apoyado de niños y adolescentes con enfermedades crónicas y sus familias. Método: revisión integradora de la literatura realizada entre julio y agosto de 2016 en las bases de datos: BDENF, LILACS, IBECS, ADOLEC, MEDLINE/PubMed y SCIELO. Los 27 estudios seleccionados fueron analizados y categorizados en los cinco pilares del auto cuidado apoyado: evaluación, asesoramiento, acuerdo, asistencia y acompañamiento. Resultados: apenas dos estudios abarcaron los cinco pilares, siendo lo más evidenciado la evaluación, sin embargo el acompañamiento se mostró imprescindible para adhesión a las terapéuticas del plan de metas. Han prevalecido las acciones, evaluaciones del estado emocional del niño/adolescente/familia e intervenciones tecnológicas para empoderar el individuo en el auto cuidado. Consideraciones finales: las referidas acciones están concentradas en países 
con sistemas de salud direccionados a las necesidades de salud de personas con enfermedades crónicas. En Brasil, eso todavía es incipiente, pues las acciones están centradas en agudizaciones.

Descriptores: Niño; Adolescente; Familia; Enfermedad Crónica; Auto Cuidado.

\section{CORRESPNDING AUTHOR Leiliane Teixeira Bento Fernandes E-mail: leilianeufpb@gmail.com}

\section{INTRODUCTION}

Supported self-care is a therapeutic design construction modality. It arose from a methodology instituted in the late 1980s for smokers by the National Cancer Institute, and is based on five pillars: assessment, counseling, agreement, care and follow-up, with the purpose of supporting the patient in the process of (re)constructing their own health ${ }^{(1-2)}$.

In the context of chronic disease, this strategy can be used from suspicion to diagnosis, and can be used throughout the life of the sick individual, with interventions to a greater or lesser frequency, according to their state. Taking into account the nature of these health conditions, which "present a gradual onset, with a long or uncertain duration, generally presenting multiple causes and the treatment for which involves lifestyle changes, in a process of continuous care that usually does not lead to cure"(3) The pillars offer an effective and less costly measure for health institutions, since it enables immediate action by the health professional.

In practice, health services do not value the specificities of each individual and base their work process on passive attitudes of the professionals through complaint-consultation and are stimulated by studies carried out by researchers and clinical specialists who do not facilitate or incorporate the participation of the user and their family in the care necessary to control the disease ${ }^{(4)}$.

It is in this context that health care networks have been advocated as a means to incorporate the collective intelligence of patients, family members, physicians and researchers thereby creating a system that explores their motivations and abilities, since they are also stakeholders in this process. In this manner they can devote time to this task and accelerate the discovery of knowledge ${ }^{(4)}$, as well as implement beneficial programs for effective care.

A model of health care that addresses actions under this perspective is the "Chronic Care Model" (CCM), with supported self-care as its fifth structuring element. This model proposes an approach that encourages health professionals to empower individuals with chronic disease to self-manage their illness process, making them protagonists of care through coresponsibility among all involved ${ }^{(1)}$. This can be done through methods that promote changes in behavior, such as operating groups; assessment of current behavior and degree of interest and confidence in the change; motivational interviews; and courses offered by health professionals covering the self-care of specific diseases ${ }^{(1-2)}$.

The implementation of strategies, in this perspective, implies that the professional is able to define roles and assignments of each individual, monitor and follow the users, manage each case in a personalized way and introduce new activities such as: shared group, continuous, peer and distance care. This practice should be developed through the setting of goals and joint care plans, assessing the health status of users, placing the individual at the center of the process, and organizing health and community resources to provide support ${ }^{(1)}$. When applying this concept to children and adolescents with chronic illness, it is understood that this capacity for the development of competencies and skills for care management must gradually evolve together with the sick individual. In addition, it is important that the family, health professionals and school as a whole are involved in order to provide the necessary support to establish responsibilities for management of the disease. Thus, the horizontal view allows an alignment among users, health professionals, researchers and families and enhances the performance expectations of actions aimed at self-care, as well as stimulating the joint elaboration of solutions ${ }^{(4)}$.

In the context of the pediatric age group, it is possible to valorize the use of a motivational process as a way of guiding professionals to recognize and lead the user to changes ${ }^{(2)}$, since even children/adolescents and their families are aware of the need to modify certain habits, however this is not always put into practice ${ }^{(5)}$. With the child, support for self-care can be provided in two main areas: family and school ${ }^{(6)}$. On the other hand, adolescents are also influenced by their peers and online health information, since electronic media are more accessible, they tend to broaden health care and education ${ }^{(7)}$.

The adoption of a pediatric model of support for self-management of the disease has the potential to improve the individual's health conditions; a factor that favors a reduction in the use of more complex services, as well as costs and burnout of the caregiver $^{(8)}$. In view of the above, the importance of using appropriate methods for the empowerment of the child/adolescent with chronic illness and their family in the self-care is emphasized. In this context, the following question has emerged: What strategies have been used for supported self-care for children/adolescents with chronic diseases and their families? Thus, the objective of this study was to analyze the scientific production between 2006 and 2015 on strategies for supported self-care for children/adolescents with chronic disease and their families.

\section{METHOD}

An integrative literature review was carried out, this is characterized as a type of review that encompasses research conducted rigorously according to different methodologies, allowing the synthesis of findings ${ }^{(9)}$. For this study, five stages were undertaken: identification of the theme and selection of the hypothesis or research question for elaboration of the integrative review; establishing criteria for inclusion and exclusion of studies/sampling or literature search; definition of the 
information to be extracted from the selected studies/categorization of the studies; evaluation of studies included in the integrative review; and interpretation of the results ${ }^{(10)}$.

The first step was guided by the following question: What have been the strategies used by health professionals for supported self-care in children/adolescents with chronic disease and their families?

The search was conducted between July and August 2016, and the terms used were the Health Sciences Descriptors (DeCS) in Portuguese and Spanish, respectively: pediatria/ pediatría; doença crônica; autocuidado [pediatrics; chronic disease; self-care]. Since some databases did not recognize these languages, we used the English language MeSH (Medical Subject Headings) terms: pediatric, chronic disease and self-management. The three terms of each language were combined with the "AND" Boolean connector. The research was carried out in two portals and four databases: BDENF/ BIREME) [Nursing Database], LILACS/BIREME [Latin American and Caribbean Literature in Health Sciences], IBECS [Spanish Bibliographical Index of Health Sciences] and Scientific Electronic Library Online (SCIELO), ADOLEC in three languages; and MEDLINE/Pubmed in English only. To select the articles the following inclusion criteria were established: presence of some strategy to support the self-care of children/adolescents with chronic diseases and/or their families; complete article available in electronic form, via proxy server of the Federal University of Paraíba; classified as original article, case study, experience report; published between 2006 and 2015; and available in Portuguese, English or Spanish. The exclusion criteria were: editorials; letters to the editor; articles of reflection; reviews; duplicates; and those that included strategies aimed for individuals over 19 years, given that the study considers patients that are adolescents or younger ${ }^{(11)}$.

Two researchers performed the search independently and concomitantly, using the same criteria for the selection of studies and data extraction. Both met at the end of these steps to reach a consensus on the selection and extraction of the data. Based on the association of the descriptors, 107 articles were found, the titles and summaries of which were exhaustively scrutinized in order to verify if they met the inclusion/exclusion criteria. After this stage, 60 articles that met the above mentioned criteria were then read in full and 27 articles were selected to compose the study sample, as shown in Table 1.

The exclusion of studies was based on the following factors: not addressing the research question (40 in MEDLINE); report (01 in MEDLINE); duplicate (02 in SCIELO); study on adults (12 in MEDLINE) or age group not defined (1 in MEDLINE); not addressing chronic disease (03 in MEDLINE); review (01 in LILACS, 01 in IBECS and 19 in MEDLINE).

Data analysis followed the guidelines of thematic analysis ${ }^{(12)}$ which is based on the steps of pre-analysis, material exploration or codification and treatment of the results obtained/interpretation. Each article was read several times, and the strategies identified were organized into at least one of the five pillars of the "Cinco As" [Five As] methodology (evaluation, counseling, agreement, care and accompaniment), emphasizing supported self-care. These procedures are important because of the need to evaluate the relationship between the individual/family and the health conditions, to provide guidance on means of change that can improve this relationship. Next, it is necessary to reach an agreement with the user/family regarding the best way to implement these changes, until the care is achieved and the subsequent follow-up of the goals established throughout the strategy ${ }^{(1)}$.

Table 1 - Distribution of the references found, excluded and selected, Brazil, 2016

\begin{tabular}{lccc}
\hline Database & Located & Excluded & Selected \\
\hline BDENF/BIREME & 00 & 00 & 00 \\
IBECS & 01 & 01 & 00 \\
ADOLEC & 01 & 00 & 01 \\
LILACS/BIREME & 01 & 01 & 00 \\
MEDLINE/Pubmed & 102 & 76 & 26 \\
SciELO & 02 & 02 & 00 \\
Total & 107 & 80 & 27 \\
\hline
\end{tabular}

\section{RESULTS}

The articles selected in the study considered all the years included in the research, however, $21(77.8 \%)$ were published between 2010 and 2015. The characteristics of these studies are shown in Chart 1.

The chronic health diseases identified in the studies analyzed were: chronic pain syndromes (04), inflammatory bowel disease (03), asthma (03), chronic kidney disease (02), special health needs (02), diseases requiring transplants (02), diabetes (01), cystic fibrosis (01), obesity (01), juvenile dermatomyositis (01), caries (01), chronic lung disease of prematurity (01), and anxiety disorder (01). In addition, four studies considered human diseases in general. Only three were performed in a primary care unit ${ }^{13-}$ 15), the remainder were in outpatient settings, specialized clinics, and children's hospitals. The categories of health professionals who participated in the studies as researchers or participants: doctor, nurse, psychologist, occupational therapist, pharmacist and nutritionist. With respect to selfcare supported, the pillar considered most in the studies as a whole was evaluation, $22(81.48 \%)$ articles included at least one action in this pillar, followed by $12(44.44 \%)$ for accompaniment; 11 (40.74\%) assistance and counseling $09(33.33 \%)$. Regarding agreement, only three $(11.11 \%)$ articles included this in their activities. Only two (7.40\%) articles ${ }^{(16-17)}$ mentioned interventions corresponding to all five pillars of supported self-care. The interventions for children and adolescents and their families found in the literature are characterized in Chart 2. 
Chart 1 - Distribution of the selected studies, according to title, year, country, study design, intervention and result, João Pessoa, Paraíba, Brazil, 2016

\begin{tabular}{|c|c|c|c|c|}
\hline Title & $\begin{array}{l}\text { Year } \\
\text { Country }\end{array}$ & $\begin{array}{l}\text { Study } \\
\text { Design }\end{array}$ & Intervention & Result \\
\hline $\begin{array}{l}\text { Predictors of Health Literacy and } \\
\text { Numeracy Concordance Among } \\
\text { Adolescents With Special Health } \\
\text { Care Needs and Their Parents }\end{array}$ & $\begin{array}{l}2015 \\
\text { EUA }\end{array}$ & $\begin{array}{l}\text { Quantitative, } \\
\text { exploratory } \\
N=278 \text { pairs }\end{array}$ & $\begin{array}{l}\text { Exploration of the } \\
\text { relationships between health } \\
\text { literacy of adolescents with } \\
\text { special health needs and } \\
\text { their parents. }\end{array}$ & $\begin{array}{l}\text { More than half of the pairs } \\
\text { have at least one member with } \\
\text { inadequate health literacy. }\end{array}$ \\
\hline $\begin{array}{l}\text { Are two youth-focused interventions } \\
\text { sufficient to empower youth with } \\
\text { chronic health conditions in their } \\
\text { transition to adult healthcare: } \\
\text { a mixed-methods longitudinal } \\
\text { prospective cohort study }\end{array}$ & $\begin{array}{c}2015 \\
\text { Canada }\end{array}$ & $\begin{array}{c}\text { Quantitative } \\
\text { qualitative, } \\
\text { prospective cohort } \\
\mathrm{N}=50\end{array}$ & $\begin{array}{l}\text { Implementation of an } \\
\text { organizational tool to } \\
\text { establish health goals for } \\
\text { young people with chronic } \\
\text { disease. }\end{array}$ & $\begin{array}{l}\text { Participants reported that } \\
\text { interventions were most useful } \\
\text { for setting goals. }\end{array}$ \\
\hline $\begin{array}{l}\text { Pediatric solid organ transplant } \\
\text { recipients: Transition to home and } \\
\text { chronic illness care }\end{array}$ & $\begin{array}{l}2015 \\
\text { EUA }\end{array}$ & $\begin{array}{l}\text { Quantitative, } \\
\text { prospective, } \\
\text { longitudinal } \\
\mathrm{N}=51\end{array}$ & $\begin{array}{l}\text { Evaluation of parents' } \\
\text { preparation for hospital } \\
\text { discharge. }\end{array}$ & $\begin{array}{l}\text { Parents prepared to leave the } \\
\text { hospital had less difficulty coping } \\
\text { with the impact of the disease on } \\
\text { the family. }\end{array}$ \\
\hline $\begin{array}{l}\text { Development and validation of a } \\
\text { generic scale for use in transition } \\
\text { programmes to measure self- } \\
\text { management skills in adolescents } \\
\text { with chronic health conditions: the } \\
\text { TRANSITION-Q }\end{array}$ & $\begin{array}{c}2015 \\
\text { Canada }\end{array}$ & $\begin{array}{l}\text { Quantitative } \\
N=369\end{array}$ & $\begin{array}{l}\text { Development of a self- } \\
\text { management skills scale for } \\
\text { adolescents with chronic } \\
\text { disease. }\end{array}$ & $\begin{array}{l}\text { The study provided evidence } \\
\text { of the reliability and validity of } \\
\text { Transition-Q. }\end{array}$ \\
\hline $\begin{array}{l}\text { iCanCope with Pain }{ }^{\mathrm{TM}} \text { : User-centred } \\
\text { design of a web- and mobile-based } \\
\text { self-management program for } \\
\text { youth with chronic pain based on } \\
\text { identified health care needs }\end{array}$ & $\begin{array}{c}2014 \\
\text { Canada }\end{array}$ & $\begin{array}{l}\text { Qualitative } \\
\mathrm{N}=23\end{array}$ & $\begin{array}{l}\text { Evaluation of the need to } \\
\text { develop an online self- } \\
\text { management program on } \\
\text { chronic pain for adolescents. }\end{array}$ & $\begin{array}{l}\text { The perceptions of young people } \\
\text { with chronic pain were crucial } \\
\text { for the development of the } \\
\text { bases of the iCanCope with Pain } \\
\text { program. }\end{array}$ \\
\hline $\begin{array}{l}\text { Using focused ethnography in } \\
\text { paediatric settings to explore } \\
\text { professionals' and parents' attitudes } \\
\text { towards expertise in managing } \\
\text { chronic kidney disease stage } 3-5\end{array}$ & $\begin{array}{l}2014 \\
\text { United } \\
\text { Kingdom }\end{array}$ & $\begin{array}{c}\text { Qualitative, } \\
\text { ethnographic } \\
\mathrm{N}=12 \text { countries, } \\
28 \text { health } \\
\text { professionals }\end{array}$ & $\begin{array}{l}\text { Discussion on the ways in } \\
\text { which health professionals } \\
\text { and parents share } \\
\text { knowledge about the child's } \\
\text { condition. }\end{array}$ & $\begin{array}{l}\text { Focused ethnography was } \\
\text { effective in gaining insights into } \\
\text { parent-professional interactions } \\
\text { in a pediatric setting. }\end{array}$ \\
\hline $\begin{array}{l}\text { Provider Awareness Alone Does } \\
\text { Not Improve Transition Readiness } \\
\text { Skills in Adolescent Patients With } \\
\text { Inflammatory Bowel Disease }\end{array}$ & $\begin{array}{l}2014 \\
\text { Holland, } \\
\text { USA and } \\
\text { Canada }\end{array}$ & $\begin{array}{c}\text { Quantitative } \\
\mathrm{N}=415 \text { patients }\end{array}$ & $\begin{array}{l}\text { Analysis of the role } \\
\text { of health professional } \\
\text { education in self- } \\
\text { management and } \\
\text { acquisition of patient skills. }\end{array}$ & $\begin{array}{l}\text { Increased awareness about the } \\
\text { aptitude of pediatric caregivers in } \\
\text { the transition process. }\end{array}$ \\
\hline $\begin{array}{l}\text { Medication treatment complexity } \\
\text { and adherence in children with } \\
\text { CKD }\end{array}$ & $\begin{array}{c}2014 \\
\text { Canada }\end{array}$ & $\begin{array}{c}\text { Quantitative, } \\
\text { transversal } \\
\mathrm{N}=558\end{array}$ & $\begin{array}{l}\text { Evaluation of the complexity } \\
\text { in management of Chronic } \\
\text { Kidney Disease (CKD) in } \\
\text { children. }\end{array}$ & $\begin{array}{l}\text { Comprehensive summary of } \\
\text { adherence or non-compliance } \\
\text { among children to the use of drugs } \\
\text { in the treatment of CKD. }\end{array}$ \\
\hline $\begin{array}{l}\text { Collaborative Chronic Care } \\
\text { Networks (C3Ns) to Transform } \\
\text { Chronic Illness Care }\end{array}$ & $\begin{array}{l}2013 \\
\text { EUA }\end{array}$ & $\begin{array}{c}\text { Quantitative } \\
N=\text { not given }\end{array}$ & $\begin{array}{l}\text { Construction of a prototype } \\
\text { health care network for the } \\
\text { chronically ill. }\end{array}$ & $\begin{array}{l}\text { C3Ns* have the potential } \\
\text { to become an active and } \\
\text { collaborative innovation network } \\
\text { for users, families, physicians and } \\
\text { researchers. }\end{array}$ \\
\hline $\begin{array}{l}\text { Complementary and alternative } \\
\text { medicine use by pediatric specialty } \\
\text { outpatients }\end{array}$ & $\begin{array}{c}2013 \\
\text { Canada }\end{array}$ & $\begin{array}{l}\text { Quantitative } \\
N=926\end{array}$ & $\begin{array}{l}\text { Analysis on the use of } \\
\text { complementary alternative } \\
\text { medicine (CAM) by families } \\
\text { of children/adolescents with } \\
\text { chronic disease. }\end{array}$ & $\begin{array}{l}\text { The results of this study indicate } \\
\text { that CAM use is high among } \\
\text { pediatric outpatients. }\end{array}$ \\
\hline $\begin{array}{l}\text { Variables associated with the use of } \\
\text { dental services among preschool } \\
\text { population in Spain: a national health } \\
\text { survey analysis }\end{array}$ & $\begin{array}{l}2012 \\
\text { Spain }\end{array}$ & $\begin{array}{l}\text { Quantitative, } \\
\text { transversal } \\
\mathrm{N}=2172\end{array}$ & $\begin{array}{l}\text { Analysis of the prevalence } \\
\text { of oral health services use } \\
\text { for preschoolers. }\end{array}$ & $\begin{array}{l}\text { The use of dental services is } \\
\text { below average for preschoolers. }\end{array}$ \\
\hline
\end{tabular}


Chart 1

\begin{tabular}{|c|c|c|c|c|}
\hline Title & $\begin{array}{l}\text { Year } \\
\text { Country }\end{array}$ & $\begin{array}{l}\text { Study } \\
\text { Design }\end{array}$ & Intervention & Result \\
\hline $\begin{array}{l}\text { Exercise training in juvenile } \\
\text { dermatomyositis }\end{array}$ & $\begin{array}{l}2012 \\
\text { Brazil }\end{array}$ & $\begin{array}{l}\text { Quantitative, } \\
\text { prospective, } \\
\text { longitudinal } \\
\mathrm{N}=10\end{array}$ & $\begin{array}{l}\text { Investigation on the effects } \\
\text { of a physical exercise } \\
\text { program in patients with } \\
\text { mild or chronic juvenile } \\
\text { dermatomyositis. }\end{array}$ & $\begin{array}{l}\text { The exercise program showed } \\
\text { a significant result in patients' } \\
\text { quality of life. }\end{array}$ \\
\hline $\begin{array}{l}\text { Evaluation, modification and } \\
\text { validation of a set of asthma } \\
\text { illustrations in children with chronic } \\
\text { asthma in the emergency department }\end{array}$ & $\begin{array}{c}2012 \\
\text { Canada }\end{array}$ & $\begin{array}{l}\text { Quantitative } \\
\qquad N=80\end{array}$ & $\begin{array}{l}\text { Validation of illustrations } \\
\text { to be incorporated into an } \\
\text { asthma self-management } \\
\text { plan. }\end{array}$ & $\begin{array}{l}\text { A total of } 15 \text { illustrations for } \\
\text { educational material on levels of } \\
\text { control and common triggers of } \\
\text { asthma were validated. }\end{array}$ \\
\hline $\begin{array}{l}\text { Factors Associated With } \\
\text { Parental Activation in Pediatric } \\
\text { Hematopoietic Stem Cell Transplant }\end{array}$ & $\begin{array}{l}2012 \\
\text { EUA }\end{array}$ & $\begin{array}{l}\text { Quantitative } \\
N=198 \text { pairs }\end{array}$ & $\begin{array}{l}\text { Analysis of the factors } \\
\text { associated to mothers' role } \\
\text { in the health of the child } \\
\text { in the mother-child dyad } \\
\text { before transplantation. }\end{array}$ & $\begin{array}{l}\text { The model identified the } \\
\text { effective role of mothers in } \\
\text { relation to self-efficacy and } \\
\text { parenting. }\end{array}$ \\
\hline $\begin{array}{l}\text { Evaluating Treatment Participation } \\
\text { in an Internet-Based Behavioral } \\
\text { Intervention for Pediatric Chronic } \\
\text { Pain }\end{array}$ & $\begin{array}{l}2012 \\
\text { EUA }\end{array}$ & $\begin{array}{l}\text { Quantitative, } \\
\text { randomized } \\
\text { controlled } \\
\mathrm{N}=26 \text { pairs }\end{array}$ & $\begin{array}{l}\text { Participation of families of } \\
\text { adolescents with chronic } \\
\text { pain in a behavioral } \\
\text { management of pain } \\
\text { program. }\end{array}$ & $\begin{array}{l}\text { The majority of families } \\
\text { participated actively in the } \\
\text { intervention and interacted with } \\
\text { an online coach for disease } \\
\text { management. }\end{array}$ \\
\hline $\begin{array}{l}\text { Paediatric parenting stress in } \\
\text { inflammatory bowel disease: } \\
\text { application of the Pediatric } \\
\text { Inventory for Parents }\end{array}$ & $\begin{array}{l}2012 \\
\text { EUA }\end{array}$ & $\begin{array}{l}\text { Quantitative } \\
N=62\end{array}$ & $\begin{array}{l}\text { Analysis of parental stress } \\
\text { and identification of } \\
\text { associated factors in parents } \\
\text { of patients with inflammatory } \\
\text { bowel disease. }\end{array}$ & $\begin{array}{l}\text { Caregivers of adolescents } \\
\text { receiving ambulatory care or in } \\
\text { the inactive phase of the disease } \\
\text { presented low rates of parental } \\
\text { stress. }\end{array}$ \\
\hline $\begin{array}{l}\text { Cognitive-behavioral treatment } \\
\text { of persistent functional somatic } \\
\text { complaints and pediatric anxiety: an } \\
\text { initial controlled trial }\end{array}$ & $\begin{array}{l}2011 \\
\text { EUA }\end{array}$ & $\begin{array}{l}\text { Quantitative, } \\
\text { controlled pilot } \\
\mathrm{N}=40\end{array}$ & $\begin{array}{l}\text { A test to assess the viability } \\
\text { and efficacy of a cognitive- } \\
\text { behavioral intervention for } \\
\text { pain among young people } \\
\text { with anxiety. }\end{array}$ & $\begin{array}{l}\text { The intervention showed } \\
\text { preliminary efficacy and } \\
\text { feasibility for application among } \\
\text { young people. }\end{array}$ \\
\hline $\begin{array}{l}\text { Provider Demonstration and } \\
\text { Assessment of Child Device } \\
\text { Technique During Pediatric Asthma } \\
\text { Visits }\end{array}$ & $\begin{array}{l}2011 \\
\text { EUA }\end{array}$ & $\begin{array}{l}\text { Quantitative } \\
\mathrm{N}=41 \\
\text { providers, } 296 \\
\text { patients }\end{array}$ & $\begin{array}{l}\text { Research and description } \\
\text { on the use of devices for } \\
\text { the treatment of asthma by } \\
\text { children. }\end{array}$ & $\begin{array}{l}\text { Deficit of health professionals in } \\
\text { the demonstration and monitoring } \\
\text { of techniques for the use of asthma } \\
\text { treatment devices by children. }\end{array}$ \\
\hline $\begin{array}{l}\text { Peer mentorship to promote } \\
\text { effective pain management in } \\
\text { adolescents: study protocol for a } \\
\text { randomised controlled trial }\end{array}$ & $\begin{array}{c}2011 \\
\text { EUA }\end{array}$ & $\begin{array}{l}\text { Quantitative, } \\
\text { randomized } \\
\text { controlled, pilot } \\
\mathrm{N}=\text { not given }\end{array}$ & $\begin{array}{l}\text { Viability test of an } \\
\text { intervention to support } \\
\text { adolescents with chronic } \\
\text { pain. }\end{array}$ & $\begin{array}{l}\text { The results of the intervention } \\
\text { will depend on the success of } \\
\text { the training program that is still } \\
\text { under development. }\end{array}$ \\
\hline $\begin{array}{l}\text { Socio-economic factors and } \\
\text { outcomes in chronic lung disease of } \\
\text { prematurity }\end{array}$ & $\begin{array}{c}2011 \\
\text { EUA }\end{array}$ & $\begin{array}{l}\text { Quantitative } \\
N=135\end{array}$ & $\begin{array}{l}\text { Evaluation of the effects } \\
\text { of economic factors in the } \\
\text { use of relief medication in } \\
\text { children with pulmonary } \\
\text { disease of prematurity. }\end{array}$ & $\begin{array}{l}\text { Non-white individuals were } \\
\text { more likely to use relief } \\
\text { medication than whites. }\end{array}$ \\
\hline $\begin{array}{l}\text { Living Profiles: Design of a health } \\
\text { media platform for teens with } \\
\text { special healthcare needs }\end{array}$ & $\begin{array}{l}2010 \\
\text { EUA }\end{array}$ & $\begin{array}{l}\text { Quantitative } \\
N=\text { not given }\end{array}$ & $\begin{array}{l}\text { Broad design of a health } \\
\text { media platform for } \\
\text { adolescents with special } \\
\text { health needs. }\end{array}$ & $\begin{array}{l}\text { Introduced the concept of a health } \\
\text { media platform to help manage } \\
\text { the well-being of adolescents with } \\
\text { special health needs. }\end{array}$ \\
\hline $\begin{array}{l}\text { Health Professionals' Attitudes } \\
\text { Towards Using a Web 2.0 Portal } \\
\text { for Child and Adolescent Diabetes } \\
\text { Care: Qualitative Study }\end{array}$ & $\begin{array}{l}2009 \\
\text { Sweden }\end{array}$ & $\begin{array}{l}\text { Qualitative } \\
\mathrm{N}=20\end{array}$ & $\begin{array}{l}\text { Investigation into the } \\
\text { attitudes of pediatric } \\
\text { professionals with the } \\
\text { introduction of a website } \\
\text { for use by patients with } \\
\text { Type } 1 \text { Diabetes. }\end{array}$ & $\begin{array}{l}\text { Pediatric practitioners reported } \\
\text { a number of positive attitudes } \\
\text { towards introducing a site into } \\
\text { their clinical practice. }\end{array}$ \\
\hline $\begin{array}{l}\text { Objective versus Subjective } \\
\text { Assessment of Oral Medication } \\
\text { Adherence in Pediatric } \\
\text { Inflammatory Bowel Disease }\end{array}$ & $\begin{array}{l}2009 \\
\text { EUA }\end{array}$ & $\begin{array}{l}\text { Quantitative } \\
N=42\end{array}$ & $\begin{array}{l}\text { Examination of prevalence } \\
\text { and frequency of lack } \\
\text { of adherence with oral } \\
\text { medication in adolescents } \\
\text { with inflammatory bowel } \\
\text { disease. }\end{array}$ & $\begin{array}{l}\text { The prevalence of nonadherence } \\
\text { to medication is no different } \\
\text { from populations with other } \\
\text { pediatric chronic diseases, and } \\
\text { the frequency of doses missed by } \\
\text { patients is } 40-50 \% \text {. }\end{array}$ \\
\hline
\end{tabular}


Chart 1 (concluded)

\begin{tabular}{|c|c|c|c|c|}
\hline Title & $\begin{array}{c}\text { Year } \\
\text { Country }\end{array}$ & $\begin{array}{l}\text { Study } \\
\text { Design }\end{array}$ & Intervention & Result \\
\hline $\begin{array}{l}\text { Small steps to health: building } \\
\text { sustainable partnerships in pediatric } \\
\text { obesity care }\end{array}$ & $\begin{array}{l}2009 \\
\text { EUA }\end{array}$ & $\begin{array}{l}\text { Quantitative } \\
\mathrm{N}=9 \text { clinics }\end{array}$ & $\begin{array}{l}\text { Project to improve the } \\
\text { quality of life in children } \\
\text { living with pediatric } \\
\text { obesity. }\end{array}$ & $\begin{array}{l}\text { The model may be applicable } \\
\text { elsewhere to develop quality of } \\
\text { life improvement programs for } \\
\text { obese children. }\end{array}$ \\
\hline $\begin{array}{l}\text { Validation of a self-report } \\
\text { questionnaire version of the Child } \\
\text { Activity Limitations Interview } \\
\text { (CALI): The CALI- } 21\end{array}$ & $\begin{array}{l}2008 \\
\text { EUA }\end{array}$ & $\begin{array}{c}\text { Quantitative, } \\
\text { exploratory } \\
N=155\end{array}$ & $\begin{array}{l}\text { Validation, internal } \\
\text { consistency and reliability of } \\
\text { the CALI- } 21 \text { questionnaire } \\
\text { in children and adolescents } \\
\text { with chronic pain. }\end{array}$ & $\begin{array}{l}\text { The CALI-21 showed good } \\
\text { internal consistency, high } \\
\text { reliability and construct validity. }\end{array}$ \\
\hline $\begin{array}{l}\text { Internet Telehealth for Pediatric } \\
\text { Asthma Case Management: Integrating } \\
\text { Computerized and Case Manager } \\
\text { Features for Tailoring a Web-Based } \\
\text { Asthma Education Program }\end{array}$ & $\begin{array}{l}2007 \\
\text { EUA }\end{array}$ & $\begin{array}{c}\text { Quantitative } \\
\mathrm{N}=\text { not given }\end{array}$ & $\begin{array}{l}\text { Description of an eHealth } \\
\text { asthma system integrated } \\
\text { with monthly phone } \\
\text { call for asthma case } \\
\text { management. }\end{array}$ & $\begin{array}{l}\text { Development of a web site by } \\
\text { doctors, researchers, designers } \\
\text { and parents to help parents } \\
\text { control their children's asthma. }\end{array}$ \\
\hline $\begin{array}{l}\text { A multi-method assessment of } \\
\text { treatment adherence for children } \\
\text { with cystic fibrosis }\end{array}$ & $\begin{array}{l}2006 \\
\text { EUA }\end{array}$ & $\begin{array}{c}\text { Quantitative } \\
N=37\end{array}$ & $\begin{array}{l}\text { Documentation of } \\
\text { adherence rates to medical } \\
\text { regimens for children with } \\
\text { cystic fibrosis using four } \\
\text { measurement methods. }\end{array}$ & $\begin{array}{l}\text { The measurement provided } \\
\text { unique information on } \\
\text { adherence rates according to } \\
\text { type of treatment component. }\end{array}$ \\
\hline
\end{tabular}

Note: * Collaborative Chronic Care Networks (C3Ns)

Chart 2 - Supported Self-care strategies for children/adolescents with chronic disease and their families according to the "5As" methodology, Brazil, 2016

\section{Methodology "5As"}

\section{Evaluation}

To evaluate the knowledge of the child/adolescent and/or family about the health condition ${ }^{(18-20)}$

Question the child/adolescent and/or his/her family about their strategies for self-care ${ }^{(19,21)}$

Ask the child/adolescent and/or family what are the barriers to self-care ${ }^{(21-23)}$

To assess the importance and degree of confidence of the child/ adolescent and/or family for self-care ${ }^{(19)}$

To evaluate the child/adolescent and/or family adherence in activities present in the self-care plan ${ }^{(17,24-29)}$

To evaluate the capacity of the patients and/or family to perform an intervention ${ }^{(14,19,30)}$

To determine the strategies used by the child/adolescent with chronic disease for rehabilitation/coping ${ }^{(21,31)}$

To assess the emotional state (depression, mood, anxiety, etc.) of the child/adolescent and/or the family, which may influence self-care actions ${ }^{(13,17,23,30,32-33)}$

To evaluate the process of health care transition (HCT) from pediatric to adult-centered health care delivery systems ${ }^{(16,18,21,34-35)}$

\section{Counseling}

Inform the child/adolescent and/or family about the symptoms of the disease and/or therapeutic measures ${ }^{(17,27,36)}$, while recognizing the cultural uniqueness ${ }^{(19)}$
Chart 2

Inform the child/adolescent and/or family that behavioral changes are as important as taking medications ${ }^{(20)}$

To report the evidence on behavioral changes in health ${ }^{(17)}$

Sharing evidence-based clinical guidelines to encourage the child/adolescent and/or family to participate in treatment ${ }^{(17,35)}$

Provide educational material on self-management ${ }^{(16,20,27,36-37)}$

Include motivational strategies ${ }^{(15)}$

\section{Agreement}

Provide possible options for defining the goal of self-care ${ }^{(16-17,21)}$

Encourage the child/adolescent to seek the help of relatives and friends for goal setting ${ }^{(17)}$

Establish shared strategies for reaching the defined goal ${ }^{(17)}$

\section{Care}

Refer the child/adolescent and/or family to a group or self-care course (self-management) ${ }^{(27)}$

Identify possible resources in the family and community that can support self-care ${ }^{(15)}$

Establish an intervention program, with weekly sessions, with the aim of improving the knowledge of the child/adolescent and/or the family and involving them in self-care ${ }^{(27,37-38)}$

Implement a self-care intervention centered on the patient and/ or his/her family ${ }^{(20,27,38)}$

Promoting multi-professional teamwork ${ }^{(20,38)}$

Interventions using technological resources, such as telemedicine, virtual reality and computer programs, in various aspects of rehabilitation ${ }^{(4,16-17,21,33,36-37)}$ 
Chart 2 (concluded)

\begin{tabular}{|l|}
\hline Accompaniment \\
\hline $\begin{array}{l}\text { Distance monitoring (by phone or mail) of the self-care } \\
\text { plan }^{(17,27,33,37)}\end{array}$ \\
\hline $\begin{array}{l}\text { Helping the person to use important community resources in } \\
\text { his/her self-care }{ }^{(15)}\end{array}$ \\
\hline Groups of pairs with professional support ${ }^{(16-17,21,27,38)}$ \\
\hline $\begin{array}{l}\text { Accompany the child/adolescent and/or the family through } \\
\text { questionnaires that assess activities of daily living, self-care and/ } \\
\text { or quality of life in a continuous form }\end{array}{ }^{(33)}$ \\
\hline $\begin{array}{l}\text { Analyzing the achievement of goals in conjunction with the } \\
\text { patient }\end{array}$ \\
\hline $\begin{array}{l}\text { Implement a self-care intervention centered on the patient and/ } \\
\text { or his/her family }\end{array}$ \\
\hline $\begin{array}{l}\text { Interventions using technological resources to empower the } \\
\text { individual in self-care actions }\end{array}$ \\
\hline
\end{tabular}

Source: Adapted from Morais HCC, Gonzaga NC, Aquino PS, Araújo TL, 2015(39).

\section{DISCUSSION}

\section{Evaluation}

Evaluation is the first pillar of supported self-care and the basis for the development of the subsequent four pillars. Several studies have investigated this activity ${ }^{(13-14,16-35)}$. One of the aspects discussed in the research was to determine whether activities for self-care management are adhered to along with therapies and skills already developed by health professionals ${ }^{(17,24-29)}$. Thus, studies in pediatrics have demonstrated a significant association between nonadherence and the frequency of medication use; since medications that needed to be taken more frequently during the day were subject to higher rates of nonadherence ${ }^{(24,28)}$, this together with the number of tablets ingested per dose $\mathrm{e}^{(28)}$. Although the data demonstrate a significant lack of adherence to medication, this problem may not be perceived by children/ adolescents and represents a timely situation for the intervention of health professionals ${ }^{(28)}$. Thus, it is fundamental to evaluate the emotional state (depression, mood, anxiety, etc.) of the child/adolescent and/or family, as it may influence self-care actions $^{(13,17,23,30,32-33)}$. This influence on children/adolescents can be seen chronic pain, for example, since it is a factor that can effect and cause limitations in the performance of activities, especially if the self-care measures are also based on the adoption of physical activities or the establishment of routines ${ }^{(23)}$.

Other studies have indicated that social class and educational level of the family were related to self-care habits ${ }^{(22,26)}$. Corroborating these findings, the literature showed that approximately $25 \%$ of adolescents from parents with low educational level also presented a deficit in the capacity to manage their health, as opposed to those who had parents with completed secondary education, for which there was a two-fold increase in the probability of adequate health literacy. Limitations in parents' education may affect their knowledge about health, adherence to treatment, understanding and following medical instructions, as well as the transition from pediatric to adult care ${ }^{(18)}$.
Regarding the transition of care, a "Transition-Q" scale has been created, this tool is used to evaluate the patient's ability to be transferred to adult care. The instrument asks the individual if he is able to answer questions by a doctor or nurse, if he helps in making decisions about his health, is responsible for managing the taking of his medication, if he speaks to or enters in contact with a physician or nurse when health problems arise, if he himself can communicate, instead of his parents, and if he is able to summarize his medical history when requested, in addition to other considerations ${ }^{(34)}$. This assessment enables both the health professionals and patient to obtain an overview of how ready the latter is to be transferred to an adult-centered care service.

Another relevant aspect is that, in general, people living with chronic disease remain in this situation for the remainder of their lives. Thus, in order to effectively monitor the family it is important that the health professional is aware of the strategies used by the child/adolescent and also by their regular caregivers, given that the latter influence their actions ${ }^{(14)}$. This concern in assessing what is done and how, promotes counseling skills.

Authors have shown that most health care providers do not provide guidance on how to use or evaluate the use of inhalers or peak flow meters by the child during pediatric asthma consultations. A study concluded that only $8.1 \%$ of children performed all steps to use these devices correctly ${ }^{(14)}$. This accountability for the use of treatment material should not be exclusive to the family or the child but rather a two-way health professional-family/ child process for effective management of asthma. In addition, it is not uncommon to search for alternative and complementary medicine (ACM) strategies for individuals living with chronic disease, mainly under the influence of parents, who expressed an interest in obtaining more information from health professionals about the efficacy and safety of these practices ${ }^{(31)}$.

Still regarding the information received, it was found that the parents' perception of their abilities to perform and/or assist in the necessary care of the children/adolescents is influenced by the information received from the health team ${ }^{(30)}$. When their children have a longer diagnosis time, parents feel more experienced and prepared to deal with the demands of care imposed by the disease ${ }^{(25)}$.

In view of the above, if the assessment of health needs is carried out in full, verifying the entire process involved in discovering the management, barriers, skills, abilities and needs of the individual with chronic illness and his/her family, the evaluation pillar will become a really firm basis for the implementation of the other phases of this therapeutic methodology.

\section{Counseling}

Counseling is an intervention that the professional can and should carry out in order to reinforce information about each specific situation and to establish help in the development of care skills, both in chronic and non-chronic conditions ${ }^{(1)}$. To this end, professionals should use material that provides information on health and disease management for both the family and patient. In this sense, a study validated 15 illustrations about asthma with children/adolescents and their parents, with the intention of incorporating these into educational material on health 
instructions and self-management skills in the long term. The authors also provided counseling sessions with a pharmacist on drug treatments in order to improve disease management ${ }^{(20)}$.

Between 2009 and 2010, a multicenter study was conducted in the Netherlands, the USA and Canada where lectures were given in outpatient clinics to advise clinical caregivers on the transition from pediatric to adult-centered care. The authors pointed out that there are major gaps in the skills needed for self-management of 18-year-old adolescents, since many are living far from their parents because they are attending college or are transferred to adult health care, solely on account of their age. The lectures resulted in an increased awareness of these professionals on the subject, without imposing preestablished behavior to make the decision whether to or not to transfer users with this profile ${ }^{(35)}$.

Regarding this age group, a survey was carried out on the implementation of a "Youth KIT" - the term is an abbreviation of Keeping It Together for Youth. This tool allows the establishment of goals - definition, identification of necessary measures and reflection on the achievement of objectives - through future planning and evaluation of the adolescent's ability to perform tasks in nine domains of life: personal, school, medical and health, social, personal care and life skills, drug management, commitments and other information. One of the positive points for the participants was the usefulness of the strategy to work towards achieving goals, while one of the negative points was the lengthiness of the material, which comprised several pages, thereby discouraging its completion and consultation ${ }^{(16)}$.

In the face of these actions, it is understood that efforts are still needed both to support children/adolescents and their families and the professionals who care for them. Motivational interviewing as an effective counseling technique and engagement of the clinical team in advocating for changes in public policy through publication of articles, discussion in community forums or at other levels ${ }^{(15)}$ may represent programs that will enable success in health practices in childhood and adolescence faced with chronic disease.

Finally, counseling goes far beyond prescribing medications or interventions; it consists of sensitizing the individual and his family to what is best suited to their reality and how they can mobilize themselves to achieve improvements.

\section{Agreement}

Agreement is a way to involve and include both patient and family in setting and monitoring goals. In this case, researchers enabled the active participation of parents of children with asthma, through a computational strategy called "Asthma manager", which allows personalization of the manager by adding activities to a pre-established list, in addition to determining the time for fulfillment of the goal and outcome. For this, there is a tab: "My Goals for a better life with asthma", with the objective of training those involved to select and achieve goals based on their reality. Thus, a motivational message is given for each selected objective, with links to relevant contents and upon completing the activity they can evaluate their progress on a fortnightly basis ${ }^{(17)}$.

Self-monitoring is an action that aims at meaningful engagement of individuals. This function allows the self-control of symptoms and favors communication with health professionals. Thus, actions based on health needs identified in focus groups with adolescents were valued for self-management of pain in Canada. Based on the results, an application called "iCanCope with Pain", to be used in smartphones and Internet platforms, was created, which allows aspects such as pain, sleep, mood, physical activity and social activity to be evaluated by the users themselves and thereby define achievable goals together with help from health professionals ${ }^{(21)}$.

Agreement is the principle that best expresses the essence of supported self-care, since it values the individual role of the person facing chronic illness in the management of their own health. Knowledge gaps have been found in the literature, since the actions linked to this pillar are still numerically scarce. Therefore, it is important to reflect on the way in which health professionals have developed their practices in relation to children and adolescents in this situation and on how much prescriptive and imposing attitudes are still the basis of their formative process.

\section{Care}

With regard to the care pillar, the implementation of a selfcare intervention centered on the individual and/or his/her family is fundamental. An example of this occurred with a cohort of children/adolescents living with juvenile dermatomyositis, where a 12-week supervised physical training program was established to improve the quality of life among this population ${ }^{(38)}$.

Another significant action in care refers to the psychosocial intervention for young people with persistent physical complaints and anxiety disorders, called Treatment of Anxiety and Physical Symptoms (TAPS). Individual sessions over a 10-week period were performed by identifying contexts in which symptoms occurred. From then on, techniques of relaxation, cognitive restructuring and exercises of exposure to anxiety inducing situations were promoted so that factors related to physical pain were identified. After treatment was completed, care was continued through reinforcements conducted by clinical psychologists twice per month ${ }^{(13)}$.

The use of technological resources to care for people living with chronic diseases was used by several researchers ${ }^{(4,16-17,21,33,36-37)}$. Access to a properly updated portal can encourage some individuals to take an active role in learning more about their illness by reading news and extending their search to other sites. In this type of intervention, attention should be paid to the fact that some people may consider themselves to be effectively educated to the point of skipping routine appointments. It is important to seek a balance between the information provided face-to-face and via the $\mathrm{Web}^{(36)}$. In addition, this reality of developed countries may be limited in poorer countries due to the unavailability of Internet access for the majority of the population.

When internet access is limited, an alternative could be the implementation of a face-to-face or telephone monitoring program. As an example, a pilot study was developed in a pediatric clinic for adolescents (14 to 18 years), in which those who had already been treated and were involved in some therapy became monitors of other adolescents attending the clinic for the same chronic disease. Thus, activities were developed for self-management of pain; information on the disease and related behavior; conducted training to deal with questions about thoughts and feelings, 
the nature of recommended treatments, which made it possible for them to discuss their pain condition with someone who has experienced this problem; participants were also encouraged to actively participate in care management skills $^{(27)}$. In this type of strategy, multi-professional assistance can significantly help with decision making support ${ }^{(19)}$.

In view of the aforementioned, it is observed that assistance to individuals with chronic disease can be performed both during routine consultations and through online strategies. However, health professionals have the responsibility to recognize that children/adolescents and their families deserve adequate attention both in the exacerbations of the chronic disease and in the period of its stability, and for each of these phases appropriate interventions will be required.

\section{Accompaniment}

Transitional clinics are resources that have been used in the United States for the follow-up of adolescents with chronic disease until they attend adult care services ${ }^{(16,34-35)}$. With regard to this situation, general interventions, which are not specific to any chronic disease $^{(16,34)}$, can reduce costs for health services and also favor the efficiency of this transfer process, considering that in this age group the problems experienced are common to several individuals, regardless of the chronic illness they are facing.

One of the studies used an online chat strategy - "Pretransfer". This is an important method of exchanging information among adolescents. The operation took place with access four nights a week, during which it was possible to either establish an individual conversation with the monitor (health professional) or in a group with their peers, posting messages and sending e-mails. In general, the participants preferred a private conversation with the health professional. It was found that this online support helped them to discover new ideas to solve their health problems. The results of this study demonstrated that the adolescents obtained self-care support for issues of transition care, university preparation, prioritization, self-understanding and learning to take responsibility for managing their own health ${ }^{(16)}$. To support individuals in these types of web-based interventions, one can use login monitoring, as demonstrated in a survey in which participants who failed to enter the site for two consecutive weeks were sent reminders by phone or e-mail ${ }^{(37)}$.

Another form of accompaniment for children and adolescents is the Collaborative Chronic Care Network (C3Ns), which, with the support of the Instituto Nacional de Diabetes e Doenças Digestivas e Renais [National Institute of Diabetes, Digestive and Kidney Diseases], has been working to transform the results of care for individuals through collaboration among physicians, researchers, individuals with Crohn's disease and ulcerative colitis and their relatives. This operational platform is a network of social constructs that involves a series of cultural changes: visualization of health care as shared work; search and use of knowledge of all those involved, building a sense of solidarity, and promoting the notion that individuals can make a difference ${ }^{(4)}$.

In view of the evidence, accompaniment through a structured transition program promotes more changes in self-management of the disease among adolescents than informal health education by professional $s^{(35)}$. Further studies are needed to assess the best way to promote health education for children and adolescents, as well as their families and/or caregivers.

Accompaniment, when performed by pairs or family caregivers, can provide better results based on the reality of each individual. Authors have reported that in emergency situations (abuse, suicidal thoughts, etc.) it was possible to manage these cases by resorting to other adolescents living with the same disease to offer accompaniment by phone, while under the supervision of professionals ${ }^{(27)}$.

Peer group therapies are alternatives used to improve adherence to care plan interventions and can be amply positive in accompaniment. In addition, analysis of disease management behavior during the transition from pediatrics to adult health care was critical for researchers who sought to identify possible intervention points and necessary changes.

\section{Study limitations}

In the data collection process, some databases could not be included due to the maintenance of the site, which may have contributed to the non-inclusion of research that would have corresponded to the subject of study. In addition, some international articles were not included due to their cost and financial limitations.

\section{Contribution to public health and Nursing}

This compilation of studies has contributed to the dissemination of knowledge regarding supported self-care. This will enable changes in the practice of care for individuals with chronic diseases in order to stimulate actions in line with the health needs arising from the epidemiological profile of such disease. For the nurse, access to information on interventions that allow an empowerment of children and adolescents with chronic disease, together with their families, can promote the implementation of actions based on the building of bonds and awareness of mutual responsibility in the effective accompaniment of these individuals.

\section{FINAL CONSIDERATIONS}

This study aimed to analyze the scientific production published between 2006 and 2015 on supported self-care strategies for children/adolescents with chronic disease and their families. It was found that most research on self-care support has been carried out in the USA and in health care settings at secondary and tertiary levels. It is emphasized that there was only one Brazilian study, however its full version was published in a foreign language.

Studies using electronic media have achieved significant results in supporting care, especially adolescents, allied to telephone communication and maintained the social interaction that could be lost through the use of the Web. The integration between technology and education (media and health platforms) has enabled self-management of several chronic diseases. However, it is necessary to train health professionals to use this type of tool.

The results suggest that interventions performed by health professionals may be more effective for individuals who have already been living with chronic diseases than those who are still trying to deal with the diagnosis. Therefore, although protocols 
containing specific guidelines do not guarantee effective care, these are instruments with potential to guide the care process. Therefore, the accompaniment pillar is essential to underscore the importance of adherence to the therapies necessary in the plan of objectives.

Finally, it should be pointed out that the health actions reported in this review are still concentrated in countries that have already established health systems for the care of people living with chronic disease, such as the USA and Canada. Nevertheless, even though interventions have been considered and researched that improve the daily life of children and adolescents with chronic disease, not all pillars of supported self-care have been fully valued; such as agreement, which was little evidenced in the literature. Supporting the management of self-care among these individuals is a process intrinsic to reaching an agreement with them based on their perspectives, in order to sensitize them to the construction of accountability and motivation in the establishment of this change. In the Brazilian reality, the concept based on this logic is still incipient, considering that we live under the optics of a health system that values care for acute problems, even with an epidemiological reality that is not in keeping with that which is most prioritized. Therefore, the relevance is evident of the insertion of self-management and support strategies for the self-care of children/adolescents with chronic disease and their families in the field of public health. This offers an alternative to the lack of effective treatment options to control them, while significantly reducing costs in therapeutic measures that are more complex and costly.

\section{FUNDING}

Coordenação de Aperfeiçoamento de Pessoal de Nível Superior (CAPES) and Conselho Nacional de Desenvolvimento Científico e Tecnológico (CNPq) - Processo 474762/2013-0.

\section{REFERENCES}

1. Mendes EV. O cuidado das condições crônicas na Atenção Primária à Saúde: o imperativo da consolidação da Estratégia da Saúde da Família [Internet]. Brasília: OPAS; 2012 [cited 2016 May 25]. Available from: http://bvsms.saude.gov.br/bvs/publicacoes/ cuidado_condicoes atencao primaria saude.pdf

2. Cavalcanti AM, Oliveira ACL (Org.). Autocuidado Apoiado: manual do profissional de saúde [Internet]. Curitiba: Secretaria Municipal de Saúde de Curitiba; 2012[cited 2016 May 25]. Available from: ftp://balcao.saude.ms.gov.br/horde/telessaude/apresentacao/2014/ autocuidado-apoiado.pdf

3. Brasil. Ministério da Saúde. Portaria $n^{\circ} 483$, de $1^{\circ}$ de abril de 2014. Redefine a Rede de Atenção à Saúde das pessoas com doenças crônicas no âmbito do Sistema Único de Saúde (SUS) e estabelece diretrizes para a organização das suas linhas de cuidado [Internet]. 2014 [cited 2016 May 25]. Available from: http://bvsms.saude.gov.br/bvs/saudelegis/gm/2014/prt0483_01_04_2014.html

4. Margolis PA, Peterson LE, Seid M. Collaborative Chronic Care Networks (C3Ns) to transform chronic illness care. Pediatrics[Internet]. 2013 [cited 2016 Jul 31];131(Suppl4):S219-23. Available from: http://pediatrics.aappublications.org/content/131/supplement_4/s219.long

5. Sousa MLXF, Silva KL, Nóbrega MML, Collet N. Self-care deficits in children and adolescents with chronic kidney disease. Texto Contexto Enferm[Internet]. 2012 [cited 2016 Jul 31];21(1):95-102. Available from: http://www.scielo.br/pdf/tce/v21n1/ en_a11v21n1.pdf

6. Moore SM, Hackworth NJ, Hamilton VE, Northam EP, Cameron FJ. Adolescents with type 1 Diabetes: parental perceptions of child health and family functioning and their relationship to adolescent metabolic control [Internet]. Health Qual Life Outcomes[Internet]. 2013 [cited 2016 Jul 31];11:50. Available from: https://www.ncbi.nlm.nih.gov/pmc/articles/pmc3614451/

7. Johnson KR, Fuchs E, Horvath KJ, Scal P. Distressed and looking for help: internet intervention support for arthritis selfmanagement. J Adolesc Health[Internet]. 2015 [cited 2016 Jul 31];56(6):666-71. Available from: http://www.jahonline.org/article/ s1054-139x(15)00077-4/fulltext

8. Henry HKM, Schor EL. Supporting self-management of chronic health problems Pediatrics[Internet]. 2015 [cited 2016 Jul 31];135(5):789-92. Available from: http://pediatrics.aappublications.org/content/135/5/789

9. Soares CB, Hoga LAK, Peduzzi M, Sangaleti C, Yonekura T, Silva DRAD. Integrative review: concepts and methods used in nursing [Internet]. Rev Esc Enferm USP[Internet]. 2014 [cited 2016 Jul 31];48(2):329-39. Available From: http://www.scielo.br/pdf/reeusp/ v48n2/0080-6234-reeusp-48-02-335.pdf

10. Mendes KDS, Silveira RCCP, Galvão CM. Integrative literature review: a research method to incorporate evidence in health care and nursing. Texto Contexto Enferm[Internet]. 2008 [cited 2016 Jul 31];17(4):758-64. Available from: http://www.scielo.br/pdf/ tce/v17n4/18.pdf

11. World Health Organization. Young People's Health - a challenge for society. Report of a WHO study group on young people and health for all. Technical Report Series 731[Internet]. Geneva: WHO; 1986 [cited 2016 Jun 29]. Available from: http://apps.who. int/iris/bitstream/10665/41720/1/who_trs_731.pdf

12. Minayo MCS (Org.). O desafio do conhecimento: pesquisa qualitativa em saúde. 14 ed. São Paulo: Hucitec; 2014.

13. Warner CM, Colognori D, Kim RE, Reigada LC, Klein RG, Browner-Elhanan KJ, et al. Cognitive-behavioral treatment of persistent functional somatic complaints and pediatric anxiety: an initial controlled trial. Depress Anxiety[Internet]. 2011 [cited 2016 Jul 
31];28(7):551-9. Available from: https://www.ncbi.nlm.nih.gov/pmc/articles/PMC3128648/

14. Sleath B, Carpenter DM, Ayala GX, Williams D, Davis S, Tudor G, et al. Communication during pediatric asthma visits and child asthma medication device technique 1 month later. J Asthma [Internet]. 2012 [cited 2016 Jul 31];49(9):918-25. Available from: Http://Www.Tandfonline.Com/Doi/Full/10.3109/02770903.2012.719250?Scroll = Top\&Needaccess = True

15. Pomietto M, Docter AD, Van Borkulo N, Alfonsi L, Krieger J, Liu LL. Small steps to health: building sustainable partnerships in pediatric obesity care. Pediatrics [Internet]. 2009 [cited 2016 Jul 31];123 (Suppl 5):S308-16. Available from: http://pediatrics. aappublications.org/content/123/supplement_5/s308.long

16. Gorter JW, Stewart D, Cohen E, Hlyva O, Morrison A, Galuppi B, et al. Are two youth-focused interventions sufficient to empower youth with chronic health conditions in their transition to adult healthcare: a mixed-methods longitudinal prospective cohort study. BMJ Open [Internet]. 2015 [cited 2016 Jul 31];5(5):E007553. Available from: http://www.ncbi.nlm.nih.gov/pmc/articles/pmc4431136/

17. Wise M, Gustafson DH, Sorkness CA, Molfenter T, Staresinic A, Meis T, et al. Internet telehealth for pediatric asthma case management: integrating computerized and case manager features for tailoring a web-based asthma education program. Health Promot Pract[Internet]. 2007 [cited 2016 Jul 31];8(3):282-91. Available from: https://www.ncbi.nlm.nih.gov/pmc/articles/ pmc2366971/

18. Chisolm DJ, Sarkar M, Kelleher KJ, Sanders LM. Predictors of health literacy and numeracy concordance among adolescents with special health care needs and their parents. J Health Commun[Internet]. 2015 [cited 2016 Jul 31];20(Suppl2):S43-9. Available from: https://www.ncbi.nlm.nih.gov/pmc/articles/pmc4699417/

19. Nightingale R, Sinha MD, Swallow V. Using focused ethnography in paediatric settings to explore professionals' and parents' attitudes towards expertise in managing chronic kidney disease stage 3-5. BMC Health Serv Res[Internet]. 2014 [cited 2016 Jul 31];18(14):403-15. Available from: https://www.ncbi.nlm.nih.gov/pmc/articles/pmc4176584/

20. Tulloch J, Irwin D, Pascuet E, Vaillancourt R. Evaluation, modification and validation of a set of asthma illustrations in children with chronic asthma in the emergency department. Can Respir J[Internet]. 2012 [cited 2016 Jul 31];19(1):26-31. Available from: https://www.ncbi.nlm.nih.gov/pmc/articles/pmc3299044/

21. Stinson JN, Lalloo C, Harris L, Isaac L, Campbell F, Brown S, et al. iCancope With Pain ${ }^{\text {TM }}$ : user-centred design of a web-and mobilebased self-management program for youth with chronic pain based on identified health care needs. Pain Res Manag[Internet]. 2014 [cited 2016 Jul 31];19(5):257-65. Available from: http://www.ncbi.nlm.nih.gov/pmc/articles/pmc4197753/

22. Collaco JM, Choi SJ, Riekert KA, Eakin MN, Mcgrath-Morrow SA, Okelo SO. Socio-economic factors and outcomes in chronic lung disease of prematurity. Pediatr Pulmonol [Internet]. 2011 [cited 2016 Jul 31];46(7):709-16. Available from: https://www. ncbi.nlm.nih.gov/pmc/articles/pmc3115434/

23. Palermo TM, Lewandowski AS, Long AC, Burant CJ. Validation of a self-report questionnaire version of the Child Activity Limitations Interview (CALI): the CALI-21. Pain[Internet]. 2008 [cited 2016 Jul 31];139(3):644-52. Available from: https://www. ncbi.nlm.nih.gov/pmc/articles/pmc3166250/

24. Blydt-Hansen TD, Pierce CB, Cai Y, Samsonov D, Massengill S, Moxey-Mims M, et al. Medication treatment complexity and adherence in children with CKD. Clin J Am Soc Nephrol [Internet]. 2014 [cited 2016 Jul 31];9(2):247-54. Available From: https:// www.ncbi.nlm.nih.gov/pmc/articles/pmc3913241/

25. Pennarola BW, Rodday AM, Mayer DK, Ratichek SJ, Davies SM, Syrjala KL, et al. Factors associated with parental activation in pediatric hematopoietic stem cell transplant. Med Care Res Rev[Internet]. 2012 [cited 2016 Jul 31];69(2):194-214. Available from: https://www.ncbi.nlm.nih.gov/pmc/articles/pmc4160822/

26. Lapresa LB, Sanz-Barbero B. Variables associated with the use of dental services among preschool population in spain: a national health survey analysis. Rev Esp Salud Publica[Internet]. 2012 [cited 2016 Jul 31];86(1):115-24. Available from: http://www.msssi. gob.es/bibliopublic/publicaciones/recursos_propios/resp/revista_cdrom/vol86/vol86_1/rs861c_115.pdf

27. Allen LB, Tsao JC, Hayes LP, Zeltzer LK. Peer mentorship to promote effective pain management in adolescents: study protocol for a randomised controlled trial. Trials [Internet]. 2011 [cited 2016 Jul 31];12:132. Available from: https://www.ncbi.nlm.nih. gov/pmc/articles/pmc3113991/

28. Hommel KA, Davis CM, Baldassano RN. Objective versus subjective assessment of oral medication adherence in pediatric. Inflamm Bowel Dis[Internet]. 2009 [cited 2016 Jul 31];15(4):589-93. Available from: https://www.ncbi.nlm.nih.gov/pmc/articles/PMC2663377/

29. Modi AC, Lim CS, Yu N, Geller D, Wagner MH, Quittner AL. A multi-method assessment of treatment adherence for children with Cystic Fibrosis. J Cyst Fibros[Internet]. 2006 [cited 2016 Jul 31];5(3):177-85. Available from: http://www.cysticfibrosisjournal. com/article/s1569-1993(06)00034-8/fulltext

30. Lerret SM, Weiss ME, Stendahl GL, Chapman S, Menendez J, Williams L, et al. Pediatric solid organ transplant recipients: transition to home and chronic illness care. Pediatr Transplant[Internet]. 2015 [cited 2016 Jul 31];19(1):118-29. Available from: https://www.ncbi.nlm.nih.gov/pmc/articles/pmc4280334/

31. Adams D, Dagenais S, Clifford T, Baydala L, King WJ, Hervas-Malo M, et al. Complementary and alternative medicine use by pediatric specialty outpatients. Pediatrics[Internet]. 2013 [cited 2016 Jul 31];131(2):225-32. Available from: http://pediatrics. aappublications.org/content/pediatrics/early/2013/01/08/peds.2012-1220.full.pdf

32. Guilfoyle SM, Denson LA, Baldassano RN, Hommel KA. Paediatric parenting stress in Inflammatory Bowel Disease: application of 
the pediatric inventory for parents. Child Care Health Dev[Internet]. 2012 [cited 2016 Jul 31];38(2):273-9. Available from: https:// www.ncbi.nlm.nih.gov/pmc/articles/pmc3123674/

33. Chira P, Nugent L, Miller K, Park T, Donahue S, Soni A, et al. Living profiles: design of a health media platform for teens with special healthcare needs. J Biomed Inform[Internet]. 2010 [cited 2016 Jul 31];43(5Suppl):S9-12. Available from: http://linkinghub. elsevier.com/retrieve/pii/s1532-0464(10)00066-3

34. Klassen AF, Grant C, Barr R, Brill H, Kraus OC, Ronen GM, et al. Development and validation of a generic scale for use in transition programmes to measure self-management skills in adolescents with chronic health conditions: the TRANSITION-Q. Child Care Health Dev[Internet]. 2014 [cited 2016 Jul 31];41(4):547-58. Available from: http://onlinelibrary.wiley.com/doi/10.1111/cch.12207/pdf

35. Fishman LN, Ziniel SI, Adrichem ME, Fernandes SM, Arnold J. Provider awareness alone does not improve transition readiness skills in adolescent patients with Inflammatory Bowel Disease. J Pediatr Gastroenterol Nutr[Internet]. 2014 [cited 2016 Jul 31];59(2):221-4. Available from: https://www.ncbi.nlm.nih.gov/pmc/articles/pmid/24762453/

36. Nordqvist C, Hanberger L, Timpka T, Nordfeldt S. Health professionals attitudes towards using a web 2.0 portal for child and adolescent diabetes care: qualitative study. J Med Internet Res[Internet]. 2009 [cited 2016 Jul 31];11(2):E12. Available from: https://www.ncbi.nlm.nih.gov/pmc/articles/pmc2762803/

37. Law EF, Murphy LK, Palermo TM. Evaluating treatment participation in an internet-based behavioral intervention for pediatric chronic pain. J Pediatr Psychol[Internet]. 2012 [cited 2016 Jul 31];37(8):893-903. Available from: https://www.ncbi.nlm.nih.gov/ pmc/articles/pmc3437681/

38. Omori $\mathrm{CH}$, Silva CA, Sallum AM, Pereira RMR, Pinto ALS, Roschel $\mathrm{H}$, et al. Exercise training in juvenile dermatomyositis. Arthritis Care Res[Internet]. 2012 [cited 2016 Jul 31];64(8):1186-94. Available from: http://onlinelibrary.wiley.com/doi/10.1002/acr.21684/pdf

39. Morais HCC, Gonzaga NC, Aquino PS, Araujo TL. Strategies for self-management support by patients with stroke: integrative review. Rev Esc Enferm USP[Internet]. 2015 [cited 2016 Jul 31];49(1):134-41. Available from: http://www.scielo.br/pdf/reeusp/ v49n1/0080-6234-reeusp-49-01-0136.pdf 